\title{
Demir Eksikliği Olan Okul Öncesi ve Okul Çağındaki Çocukların Serum Çinko Seviyelerinin Değerlendirilmesi: Kesitsel Vaka Kontrol Çalışması
}

\author{
The Evaluation of Zinc Levels of Preschool And School-Aged Children With Iron Deficiency: \\ A Cross-Sectional Case-Control Study
}

\author{
Uzm. Dr. Ömer KARTAL ${ }^{1}$, Doç. Dr. Orhan GÜRSEL ${ }^{1}$
}

1. Gülhane Eğitim ve Araştırma Hastanesi, Çocuk Hematolojisi ve Onkolojisi Kliniği, Ankara, Türkiye

\section{ÖZET}

Amaç: Dünyada hala ek sik gözlenen nutrisyonel eksiklikler demir ve Cinko eksiklikleridir. Günümüzde bu nutrisyonel eksiklikler sadece gelişmekte olan ülkelerin değil tüm dünyanın önemli bir problemidir. Bu çalısmanın amacı, okul öncesi ve okul çağında demir eksikliği olan çocuklarda serum Çinko seviyelerini karssılaștırmak ve eritrosit indekslerine olan etkilerin değerlendirmektir

Gerecler ve Yöntem: Calısmaya Ocak 2011 ile Ağustos 2017 tarihleri arasında Gülhane Eğitim ve Araştırma Hastanesi çocuk hematolojisi polikliniğine basvuran, serum Cinko ve demir düzeyleri bakılmış çocuklar dahil edildi. Hastalar okul öncesi (2-5 yas) ve okul çağl (6-12 yas) olarak 2 gruba ayrild ve grupların serum demir ve Çinko düzeyleri değerlendirildi.

Bulgular: Demir eksikliği anemisi olan gruplarda serum Çinko düzeyleri, kontrol gruplarına göre istatistiksel olarak anlaml bir sekilde düsük bulundu $(p<0.05)$. Yapılan korelasyon analizinde serum Çinko düzeyi ile hemoglobin düzeyi arasinda istatistiksel olarak anlamlı ve pozitif yönlü bir korelasyon saptand $(p<0.05)$

Sonuç: Çalışma sonucunda elde ettiğimiz veriler Çinkonun anemi için bağımsız bir risk faktörü olduğu yönündedir. Demir eksikliği anemisi olan çocuklarda demir tedavisine rağmen düzelmeyen anemi varllğı̆nda Çinko desteği düşünülmelidir

Anahtar Kelimeler: çinko, demir eksikliği anemisi, nutrisyonel eksiklik

\section{ABSTRACT}

Objective: Iron and zinc deficiencies are still the most common nutritional deficiencies in the world. Nowadays, these nutritional deficiencies are a major problem not only for the developing countries but also for the whole world. The aim of this study was to compare serum zinc levels in children with iron deficiency in preschool and school-aged periods and to evaluate their effects on erythrocyte index.

Material and Methods: The children, whose serum zinc and iron levels were checked, were recruited from outpatient pediatric hematology clinic at Gülhane Training and Research Hospital in the period from January 2011 till August 2017.

Participants were divided into 2 groups as preschool (2-5 years) and school-aged (6-12 years) periods and serum iron and zinc levels were evaluated.

Results: Serum zinc levels were significantly lower in the groups with iron deficiency anemia compared to the control groups $(p<0.05)$.

\section{İletișim}

Sorumlu Yazar: Uzm. Dr. Ömer KARTAL

Adres: Gülhane Eğitim ve Araştırma Hastanesi, Çocuk Hematolojisi ve Onkolojisi Kliniği, 06300, Keçiören /Ankara, Türkiye

Tel: +90 (542) 4610715

E-Posta: dr.omerkartal@hotmail.com

Makale Gelis: 26.02.2016

Makale Kabul: 18.06.2019

DOI: http://dx.doi.org/10.16948/zktipb.532853
Correlation analysis revealed a statistically significant and positive correlation between serum zinc and hemoglobin levels $(p<0.05)$.

Conclusion: The data obtained from the study showed that serum zinc level is an independent risk factor for anemia. In children with iron deficiency anemia, zinc supplementation should be considered in the presence of anemia that does not improve despite the iron replacement.

Keywords: zinc, iron deficiency anemia, nutritional deficiency

\section{GíRiș}

Dünyada hala ek sik gözlenen nutrisyonel eksiklikler demir ve Çinko eksiklikleridir (1). Günümüzde bu nutrisyonel eksiklikler sadece gelişmekte olan ülkelerin değil tüm dünyanın önemli bir problemidir (2). Hem demir hem de Çinko eksikliği benzer şikayet ve bulgulara yol açabildiği için çoğunlukla Çinko eksikliği gözden kaçmaktadır. Dünya nüfusunun yaklaşı \%30'u anemiye sahiptir ve bu vakalarında yaklașık \%50'si demir eksikliğinden kaynaklanmaktadır (3). Demir DNA sentezi, enzimatik süreçler ve mitokondriyal enerji üretimi gibi çeşitli hücresel fonksiyonlar için gereklidir (3). Eksikliğinde ise kognitif fonksiyonlarda bozulma, okul başarısında azalma, gelişme geriliği, enfeksiyonlara artmış duyarlılık ve egzersiz kapasitesinde azalma gözlenebilir (4).

Cinko esansiyel bir eser elementtir ve eksikliği açısından dünya nüfusunun yaklaşık $\% 25^{\prime}$ ' risk altındadır (3). Metalloproteinlerin ve bazı enzimlerin yapısına katılır (5). Hem sentezinde görevli alfa-aminolevulinik asit dehidrataz enzimini katalize eder (6). Eritroid hücre büyümesinin en önemli düzenleyicisi olan Gfi-1B zinc finger protein yapısına katılır ve böylece hematopoezi destekler (5). Son yapılan çalıșmalar Çinkonun ayrıca anti-oksidan, anti-inflamatuar, immün stimülatör, anti-kanser ve nöroprotektif etkilere sahip olduğunu ortaya koymuștur (7). Eksikliğinde ise büyüme gelișme gerili$\breve{g} \mathrm{i}$, kognitif fonksiyonlarda bozulma, enfeksiyonlara artmış duyarlılık, üreme fonksiyonlarında bozulma ve diyare gözlenebilir (8).

Mevcut çalışmalar demir eksikliği ve Çinko eksikliğinin özellikle sosyo-ekonomik yönden geri kalmış toplumlarda yaygın olduğunu göstermektedir $(1,2,7)$. Ancak yapılan çalışmalar genellikle bir nutrisyonel eksiklik üzerine yoğunlaşmıștır. Mevcut literatür tarama sonucumuza göre, eş zamanlı demir ve Çinko eksikliğinin çocukluk çağı dönemlerinde karşılaştırılmasına ait çalışmalar yetersizdir. 
Bu çalışmadaki amacımız, okul öncesi ve okul çağında demir eksikliği olan çocuklarda serum Çinko seviyelerini karşılaştırmak ve eritrosit indekslerine olan etkilerini değerlendirmektir.

\section{GEREÇ ve YÖNTEM}

Çalışmaya Ocak 2011 ile Ağustos 2017 tarihleri arasında Gülhane Eğitim ve Araştırma Hastanesi çocuk hematolojisi polikliniğine başvuran, serum Çinko ve demir düzeyleri bakılmış hastalar dahil edildi ve okul öncesi (2-5 yaş) ve okul çağ 1 (6-12 yaş) olarak 2 gruba ayrıldı. Hastaların dosyaları retrospektif olarak taranarak serum Çinko, hemoglobin $(\mathrm{Hb})$, ortalama eritrosit hacmi (MCV), ortalama eritrosit hemoglobini $(\mathrm{MCH})$, ortalama eritrosit hemoglobin konsantrasyonu (MCHC), eritrosit dağllım genişliği (RDW) demir, total demir bağlama kapasitesi (TDBK), Ferritin, transferrin satürasyon indeksi (TSI) kaydedildi.

Çalışmadan çıkarılma kriterleri; Kronik hastalık, enfeksiyon, dermatit, inflamatuar hastalık, hematolojik hastalık, açıklanamayan hematolojik parametre, son 3 ayda Çinko yada demir tedavisi alma, intestinal malabsorbsiyon sendromu ve verileri eksik olma olarak belirlendi.

Hastaların eritrosit indeksleri otomatik kan sayım cihazı LH 780 (Beckman Coulter, CA, USA), serum Çinko düzeyi atomik absorbsiyon spektrofotometresi AAnalyst 600 (PerkinElmer, Baesweiler, Germany), demir, total demir bağlama kapasitesi ve Ferritin ADVIA ${ }^{\circledR} 1800$ (Siemens, Erlangen, Germany) ile ölçüldü. Hgb düzeyi $<11 \mathrm{gr} / \mathrm{dL}$ olan hastalar anemi; Serum Ferritin düzeyi $<12 \mathrm{ng} / \mathrm{ml}$ ve transferrin satürasyon indeksi $<16 \%$ olan hastalar demir eksikliği olarak kabul edildi. Anemi ve demir eksikliğinin birlikte olduğu hastalar demir eksikliği anemisi olarak Kabul edildi. Transferrin satürasyon indeksi (serum demir düzeyi/total demir bağlama kapasitesi x100) formülü ile hesaplandı. Serum Çinko seviyesi $<70 \mathrm{mcg} / \mathrm{dL}$ ise Çinko eksikliği kabul edildi. Çalışma protokü Keçiöğren Eğitim ve Araştırma Hastanesi Etik komitesi tarafindan onayland 1 ve Helsinki bildirgesine göre yürütüldü.
İstatistiksel analiz: Verilerin analizi SPSS 21.0 paket programında yapıldı. Sürekli değişkenler ortalama+standart sapma olarak hesaplandi. Verilerin normal dağılıma uygunluğu ve homojenitesi için Shapiro-Wilk ve Levine testleri kullanıldı. Sonuçlar arasindaki korelasyon Pearson korelasyon testi ile değerlendirildi. Grupların karşılaştırılmasında $\mathrm{Ba}-$ $\breve{g} 1 m s ı z$ t testi ve Ki kare testleri kullanıldı. Sonuçlar $p<0,05$ ise istatiksel olarak anlamlı olarak kabul edildi.

\section{BULGULAR}

Demografik özellikler ve biyokimyasal bulgular Tablo 1 da özetlendi. Çalışmaya, serum Çinko düzeyi bakılmış okul öncesi 46, okul dönemi 52 demir eksikliği anemisi olgusu ile her iki döneme yaş ve cinsiyet olarak uygun $35^{\prime}$ er kişiden oluşan kontrol grupları dahil edildi. Okul öncesi döneme ait demir eksikliği anemisi ve kontrol gruplarının ortalama yaşları sıra ile $39,8 \pm 8,3 ; 44 \pm 3,1$ ay olarak bulundu ( $\mathrm{p}>0.05)$, (Tablo 1). Okul dönemine ait demir eksikliği anemisi ve kontrol gruplarının ortalama yaşları ise sıra ile $98,7 \pm 22,8 ; 107,2 \pm 22,1$ ay olarak bulundu ( $\mathrm{p}>0.05)$, (Tablo 1). Erkek/kadın oranı okul öncesi dönemde demir eksikliği anemisi ve kontrol gruplarında sıra ile $21 / 25 ; 19 / 16$ ve okul döneminde ise sira ile 24/28; $17 ; 18$ olarak bulundu ( $\mathrm{p}>0.05)$ (Tablo 1).

Demir eksikliği anemisi ve kontrol gruplarının okul öncesi dönemde ki ortalama serum Çinko düzeyleri sira ile $83,2 \pm 17,1 \mathrm{mcg} / \mathrm{dL} ; 97,3 \pm 15,7 \mathrm{mcg} /$ dL ve okul döneminde ise sira ile $81,7 \pm 14,7 \mathrm{mcg} /$ $\mathrm{dL} ; 95 \pm 17,5 \mathrm{mcg} / \mathrm{dL}$ olarak bulundu $(\mathrm{p}<0.05)$, (Tablo 1). Çinko eksikliği demir eksikliği anemisi olan okul öncesi çocukların \%15.1'inde, okul dönemindekilerin ise \%21.3'inde saptand.

Yapılan korelasyon analizinde serum Çinko düzeyi ile hemoglobin düzeyi arasında istatistiksel olarak anlamlı ve pozitif yönlü bir korelasyon saptand $1(\mathrm{p}<0.05)$, ancak serum Çinko ve Ferritin düzeyi arasında ise istatistiksel olarak anlamlı olmayan pozitif yönlü bir korelasyon bulundu $(\mathrm{p}>0.05)$, (Tablo 2), (Şekil).

Tablo 1: Hastaların gruplara göre demografik ve laboratuvar değerlerinin karşılaştırılması.

\begin{tabular}{|c|c|c|c|c|c|c|}
\hline & \multicolumn{3}{|c|}{ Okul öncesi dönem } & \multicolumn{3}{|c|}{ Okul dönemi } \\
\hline & DEA $(n=46)$ & Kontrol $(n=35)$ & $\mathbf{p}$ & $\operatorname{DEA}(n=52)$ & Kontrol $(n=$ & $\mathbf{p}$ \\
\hline Yaş, ay & $39,8 \pm 8,3$ & $44 \pm 3,1$ & $>0,05$ & $98,7 \pm 22,8$ & $107,2 \pm 22,1$ & $>0,05$ \\
\hline Cinsiyet (Erkek/Kız), n & $21 / 25$ & $19 / 16$ & $>0,05$ & $24 / 28$ & $17 / 18$ & $>0,05$ \\
\hline Çinko (mcg/dL) & $83,2 \pm 17,1$ & $97,3 \pm 15,7$ & $<0,05$ & $81,7 \pm 14,7$ & $95 \pm 17,5$ & $<0,05$ \\
\hline $\mathrm{Hb}(\mathrm{gr} / \mathrm{dl})$ & $9,7 \pm 1$ & $12,8 \pm 0,5$ & $<0,05$ & $10,2 \pm 0,6$ & $12,6 \pm 0,7$ & $<0,05$ \\
\hline MCV & $63,1 \pm 5$ & $73,6 \pm 1,7$ & $<0,05$ & $72,2 \pm 3$ & $79,7 \pm 2,5$ & $<0,05$ \\
\hline МCH & $20,4 \pm 1,6$ & $26,1 \pm 1,1$ & $<0,05$ & $23,1 \pm 1,7$ & $28,2 \pm 2,1$ & $<0,05$ \\
\hline MCHC & $29,2 \pm 1,1$ & $33,6 \pm 0,9$ & $<0,05$ & $31,2 \pm 1,4$ & $34,3 \pm 1,3$ & $<0,05$ \\
\hline RDW & $17,9 \pm 2,7$ & $12,3 \pm 0,4$ & $<0,05$ & $17,8 \pm 2,2$ & $12,4 \pm 0,7$ & $<0,05$ \\
\hline Demir (meg/dL) & $21,7 \pm 8$ & $68,5 \pm 17,6$ & $<0,05$ & $30,6 \pm 8,9$ & $71,9 \pm 13,2$ & $<0,05$ \\
\hline Ferritin (ng/ml) & $6,3 \pm 2,8$ & $28,7 \pm 16,3$ & $<0,05$ & $7,4 \pm 2,8$ & $33,9 \pm 14,1$ & $<0,05$ \\
\hline TSİ (\%) & $5,7 \pm 2,3$ & $16,9 \pm 4,6$ & $<0,05$ & $9,5 \pm 3,1$ & $18,8 \pm 4,1$ & $<0,05$ \\
\hline TDBK (mcg/dL) & $\underline{468,9 \pm 18,7}$ & $355,9 \pm 30,3$ & $\leq 0,05$ & $\underline{451,5 \pm 13,1}$ & $\underline{344,3 \pm 24,4}$ & $\leq 0,05$ \\
\hline
\end{tabular}

Hb: Hemoglobin; MCV: Ortalama eritrosit hacmi; MCH: Ortalama eritrosit hemoglobini; MCHC: Ortalama eritrosit hemoglobin konsantrasyonu; RDW: Eritrosit dağılım genişliği; TSİ: Transferrin saturasyon indeksi; TDBK: Total demir bağlama kapasitesi. 
Tablo 2: Serum çinko düzeyinin hemogram ve demir parametreleri ile karşılaştırılması.

\begin{tabular}{|l|l|l|l|l|}
\hline \multirow{2}{*}{} & \multicolumn{2}{|l|}{ Okul öncesi dönem } & \multicolumn{2}{l}{ Okul dönemi } \\
\cline { 2 - 5 } & r & p & r & p \\
\hline Hb (gr/dl) & 0,356 & $<\mathbf{0 , 0 5}$ & 0,295 & $<\mathbf{0 , 0 5}$ \\
\hline MCV & 0,383 & $<\mathbf{0 , 0 5}$ & 0,329 & $<\mathbf{0 , 0 5}$ \\
\hline MCH & 0,358 & $<\mathbf{0 , 0 5}$ & 0,411 & $<\mathbf{0 , 0 5}$ \\
\hline MCHC & 0,367 & $<\mathbf{0 , 0 5}$ & 0,305 & $<\mathbf{0 , 0 5}$ \\
\hline RDW & $-0,352$ & $<\mathbf{0 , 0 5}$ & $-0,272$ & $<\mathbf{0 , 0 5}$ \\
\hline Demir (mcg/dL) & 0,314 & $<\mathbf{0 , 0 5}$ & 0,255 & $<\mathbf{0 , 0 5}$ \\
\hline Ferritin (ng/ml) & 0,103 & $>0,05$ & 0,159 & $>0,05$ \\
\hline TSİ(\%) & 0,335 & $<\mathbf{0 , 0 5}$ & 0,224 & $<\mathbf{0 , 0 5}$ \\
\hline & & & & \\
\hline
\end{tabular}
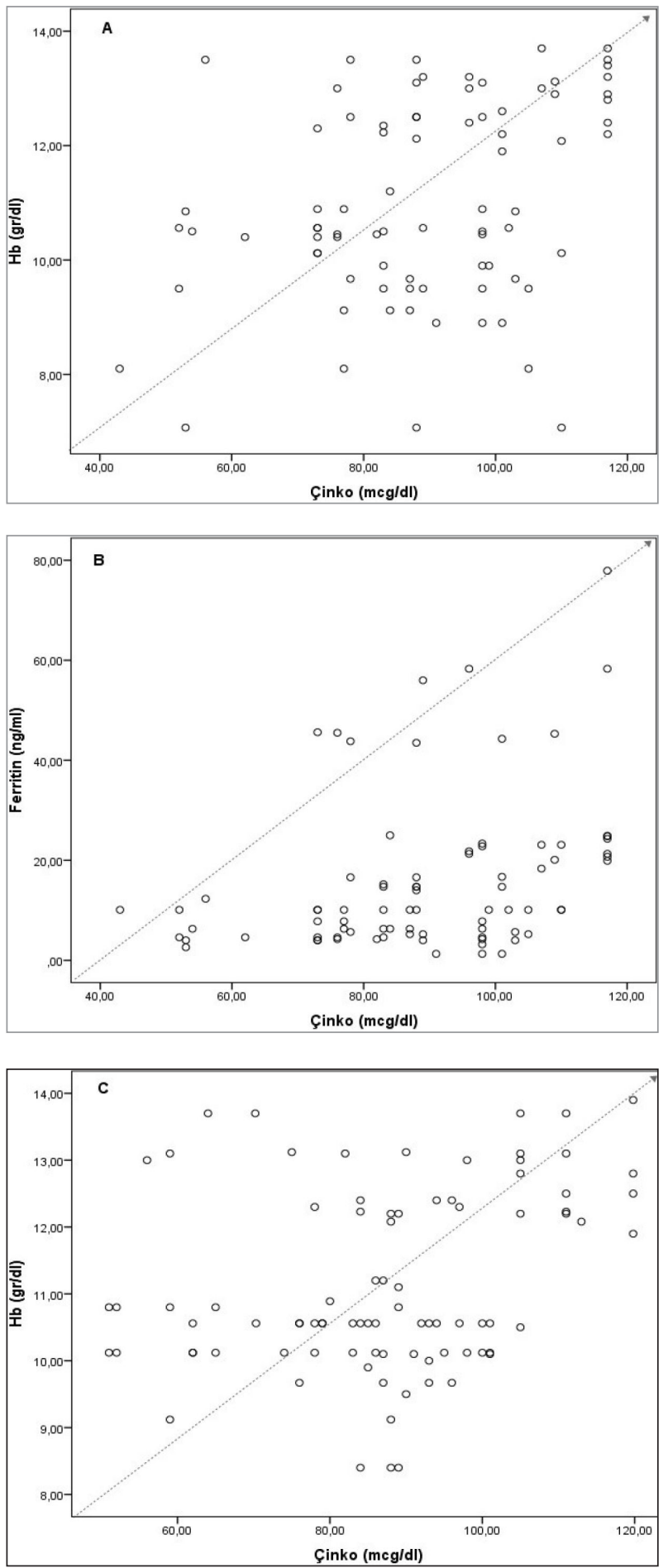

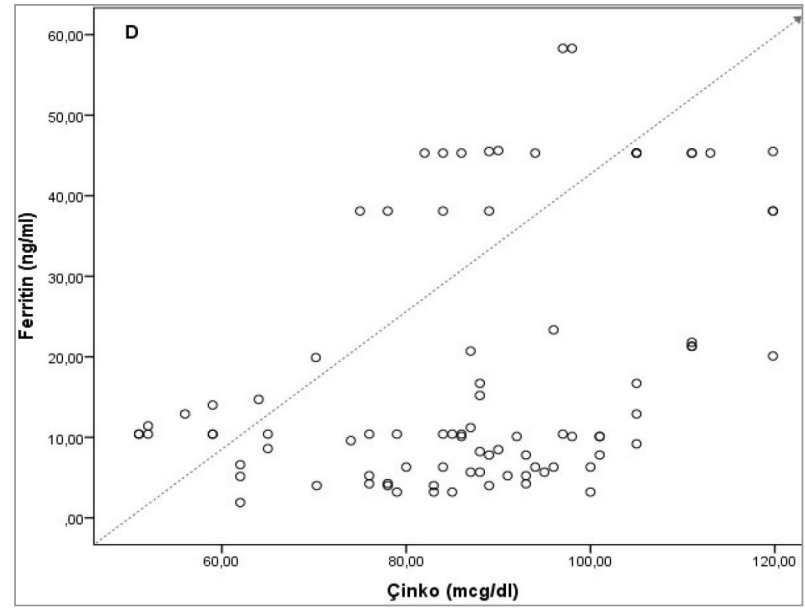

Sekil:

Ả. Okul öncesi çalışma grubunda Hb-Çinko ilișkisi B. Okul öncesi çalıșma grubunda Ferritin-Cinko ilișkisi C. Okul döneminde çalısma çalışma grubunda Ferritin-Çinko ilişkisi C. Okul döneminde çalışma
grubunda Hb-Çinko ilişkisi D. Okul döneminde çalışma Grubunda Ferritin-Çinko iliş̧kisi.

\section{TARTIŞMA}

Tüm dünyada en sik nütrisyonel eksiklik demir eksikliğidir (9). Özellikle, gelişmekte olan ülkelerde, demir eksikliğine diğer nütrisyonel eksiklikler, sıklıklada Çinko eksikliği eşlik edebilir (10). Çinko metalloproteinlerin ve çok sayıda enzimin yapısına katılır (11). Çinko bilinen birkaç mekanizma ile anemiye neden olabilmektedir. Eritroid hücre büyümesinin en önemli düzenleyicisi olan Gfi-1B zinc finger protein yapısına katılarak hematopoezi destekler ve hem sentezinde görevli alfa-aminolevülinik asit dehidrataz enziminin yapısına katılır $(12,13)$. Çinko bağımlı bir enzim olan ve oksidatif strese karşı hücreyi koruyan, eritrosit bakır-Çinko süperoksit dismutaz aktivitesi Çinko eksikliğinde azalır ve buna bağlı olarakta eritrosit yaşam süresi kısalır (14). Ayrıca, ciddi demir eksikliği anemisinde eritrositler içinde çok sayıda Çinko-protoporfirin oluşmakta ve bunun sonucunda serum Çinko seviyeside azalmaktadır (6).

Çinko özellikle kırmızı ette yüksek oranda bulunur (15). Gelişmekte olan ülkelerde düşük oranda kırmızı et tüketimi ve yüksek oranda fitat içeren tahıllı gidaların tüketilmesi nedeniyle Çinko eksikliğine sik rastlanmaktadır (15). Bu nedenle dünyanın farklı bölgelerinde hatta aynı ülkenin farklı alanlarında yapılmıș çalıșmalarda birbirinden farklı Çinko eksikliği oranları bulunmuştur (16-18).

Hindistandan Kapil ve arkadaşları yapmış oldukları çalışmada 5 yaş altı çocuklarda Çinko eksikliği prevelansını sinır $65 \mu \mathrm{g} / \mathrm{dl}$ alındığında ortalama \%43.8; İrandan Abbaspour ve arkadaşlarıda 5 yaş altı çocuklarda Çinko eksikliği prevelansını sınır $65 \mu \mathrm{g} / \mathrm{dl}$ alındiğında ortalama \%12.5 olarak bulmuşlardır $(16,17)$. Türkiyeden Arcagök ve arkadaşları ise yaş ortalaması $5.7 \pm 4.9$ olan demir eksikliği ve demir eksikliği anemisinin olduğu çalışma grubunda Çinko eksikliği oranını \%9.2 olarak bulmuşlardır (18). Bizim yapmış olduğumuz çalışmada ise okul öncesi dönemde sinır değer $70 \mu \mathrm{g} / \mathrm{dl}$ alındığında çalışma grubunda Çinko eksikliği oranı \%15.1 olarak bulundu. Şahin ve arkadaşları demir eksikliği anemisi olan ve yaşları 1-12 aralığında olan çocuklarda Çinko eksikliği prevelansını sınır 
değer $75 \mu \mathrm{g} / \mathrm{dl}$ alındığında $\% 49.2$ olarak bulmuşlardır (19). Abbaspour ve arkadaşlarıda 5-14 yaş arası çocuklarda Çinko eksikliği prevelansını ortalama \%7.3 olarak bulmuşlardır (17). Bizim yapmış olduğumuz çalışmada ise okul döneminde sınır değer 70 $\mu \mathrm{g} / \mathrm{dl}$ alındığında çalışma grubunda Çinko eksikliği oranı \%21.3 olarak bulundu. Biz kendi çalışmamız ve diğer çalışmalarda bulunan farklı Çinko eksikliği oranlarını kullanılan farklı sınır değerleri, beslenme alışkanlıkları ve sosyoekonomik farklılıklardan kaynaklandığını düşündük. Arcagök ve arkadaşları yaşları 6 ay-18 yaş arasında değişen çocuklarda yaş grupları ile serum Çinko düzeyi arasında anlamlı istatistiksel fark saptamamışlardır (18). Benzer şekilde Wouwe ve arkadaşları da yaşları 1-166 ay arasında değişen çocuklarda yaş ile serum Çinko düzeyi arasında bir korelasyon saptamamışlardır (20). Bizim yapmış olduğumuz çalışmada da bulduğumuz sonuçlar benzer şekilde yaş ile serum Çinko düzeyi arasında bir ilișki olmadığg yönündedir.

Abbaspour ve arkadaşları 27 okul öncesi ve 127 okul döneminde olan çocukta yapmış oldukları çalışmada serum Çinko düzeyi ile hemoglobin arasında anlamlı bir korelasyon saptamış; fakat serum Çinko düzeyi ile Ferritin arasında korelasyon bulamamışlardır (17). Houghton ve arkadaşları da okul dönemindeki çocuklarda yapmış oldukları çalışmada serum Çinko düzeyi ile Ferritin arasında anlamlı bir ilişki gösterememiştir (21). Hacıbekiroğlu ve arkadaşları 115 demir eksikliği anemisi olan hastada yapmış oldukları çalışmada serum Çinko düzeyi ile hemoglobin, MCV, serum demir, Ferritin ve TDBK arasında bir korelasyon gösterememiştir (5). Bizim yapmış olduğumuz çalışmada ise serum Çinko düzeyi ile hemoglobin arasında anlamlı korelasyon bulundu; fakat Ferritin ile arasinda anlamlı bir korelasyon bulunmadi. Serum Çinko ve Ferritin arasında bir korelasyon olmaması Çinkonun bağıms1z bir anemi nedeni olabileceğini gösterebilir. $\mathrm{Bu}$ durumun, ayrıca süt ürünlerinden fazla beslenme ve geleneksel içecek olan çayın serum Çinko düzeyinden daha çok Ferritin üzerine olumsuz etkisinden kaynaklanabileceğini düşündük. Farklı çalışmalarda farklı korelasyonlar bulunma nedeni olarak ise çalışmaya vakaların dahil edilme kriterlerinden kaynaklanabileceğini düșündük.

Sonuç olarak, çalışma sonucunda elde ettiğimiz veriler Çinkonun anemi için bağımsız bir risk faktörü olduğu yönündedir. Fiziksel ve mental sorunlara yol açabilen Çinko eksikliği, özellikle demir eksikliği anemisi olan hastalarda akılda tutulmal1dır. Demir eksikliği anemisi olan çocuklarda demir tedavisine rağmen düzelmeyen anemi varlığında Çinko desteği düşünülmelidir.

\section{KAYNAKLAR}

1. Bains K, Kaur H, Bajwa N, et al. Iron and zinc status of 6-month to 5-year-old children from low-income rural families of Punjab, India. Food Nutr Bull 2015;36:254-263.

2. Roba KT, O'Connor TP, Belachew T, et al. Concurrent iron and zinc deficiencies in lactating mothers and their children 6-23 months of age in two agroecological zones of rural Ethiopia. Eur $J$ Nutr 2018; 57:655-667.
3. Bjørklund $G$, Aaseth J, Skalny AV, et al. Interactions of iron with manganese, zinc, chromium, and selenium as related to prophylaxis and treatment of iron deficiency. J Trace Elem Med Biol 2017;41:41-53.

4. Jin HJ, Lee JH, Kim MK. The prevalence of vitamin D deficiency in irondeficient and normal children under the age of 24 months. Blood Res. 2013;48:40-45.

5. Hacibekiroglu T, Basturk A, Akinci S, et al. Evaluation of serum levels of zinc, copper, and Helicobacter pylori $\operatorname{Ig} G$ and $\operatorname{IgA}$ in iron deficiency anemia cases. Eur Rev Med Pharmacol Sci 2015; 19:4835-4840.

6. Kelkitli E, Ozturk N, Aslan NA, et al. Serum zinc levels in patients with iron deficiency anemia and its association with symptoms of iron deficiency anemia. Ann Hematol 2016;95:751-756.

7. Motadi SA, Mbhenyane XG, Mbhatsani HV, et al. Prevalence of iron and zinc deficiencies among preschool children ages 3 to $5 y$ in Vhembe district, Limpopo province, South Africa. Nutrition 2015;31:452-458.

8. Siyame EW, Hurst $R$, Wawer AA, et al. A high prevalence of zinc-but not irondeficiency among women in rural Malawi: a cross-sectional study. Int J Vitam Nutr Res 2013;83:176-187.

9. Yoon JW, Kim SW, Yoo EG, et al. Prevalence and risk factors for vitamin $D$ deficiency in children with iron deficiency anemia. Korean J Pediatr 2012;55:206-211.

10. Harika R, Faber M, Samuel F, et al. Micronutrient status and dietary intake of iron, Vitamin A, iodine, folate and zinc in women of reproductive age and pregnant women in Ethiopia, Kenya, Nigeria and South Africa: A systematic review of data from 2005 to 2015. Nutrients 2017;9:1096.

11. Fukunaka A, Fujitani Y. Role of zinc homeostasis in the pathogenesis of diabetes and obesity. Int J Mol Sci 2018;19:476.

12. Anguita E, Candel FJ, Chaparro A, et al. Transcription Factor GFI1B in Health and Disease. Front Oncol 2017;7:54.

13. Besur S, Hou W, Schmeltzer P, et al. Clinically important features of porphyrin and heme metabolism and the porphyrias. Metabolites 2014;4:977-1006.

14. Salmonowicz B, Krzystek-Korpacka M, Noczyńska A. Trace Elements, Magnesium, and the Efficacy of Antioxidant Systems in Children with Type 1 Diabetes Mellitus and in Their Siblings. Adv Clin Exp Med 2014;23:259-268.

15. Onukwuli VO, Ikefuna AN, Nwokocha AR. Relationship between Zinc Levels and Anthropometric Indices among School-aged Female Children with Sickle Cell Anemia in Enugu, Nigeria. 2018;20:1461-1467.

16. Kapil U, Jain K. Magnitude of zinc deficiency amongst under five children in India. Indian J Pediatr 2011;78:1069-1072.

17. Abbaspour N, Wegmueller R, Kelishadi R, et al. Zinc status as compared to zinc intake and iron status: A case study of Iranian populations from Isfahan Province. Int $J$ Vitam Nutr Res 2013;83:335-345.

18. Arcagök B, Özdemir N, Yıldız İ, et al. Çocukluk çă̆ında demir eksikliğinin kan Çinko düzeyi ile ilişkisi. Çocuk Sağlığ ve Hastalıkları Dergisi 2013;56:63-70.

19. Şahin Y, Şahin DA. Demir eksikliği anemisinde serum Çinko düzeylerinin değerlendirilmesi. Göztepe Tıp Dergisi 2007;22:5357.

20. Van Wouwe JP, Waser I. Comparison between total and ultrafiltrable serum zinc as test to diagnose zinc deficiency in infants and children. Biol Trace Elem Res 1994;40:203-211.

21. Houghton LA, Parnell WR, Thomson CD, et al. Serum Zinc Is a Major Predictor of Anemia and Mediates the Effect of Selenium on Hemoglobin in School-Aged Children in a Nationally Representative Survey in New Zealand. J Nutr 2016;146:1670-1676. 